\title{
Protein kinase A-mediated CREB phosphorylation is an oxidant-induced survival pathway in alveolar type II cells
}

\author{
Christy A. Barlow - Kajorn Kitiphongspattana • \\ Nazli Siddiqui - Michael W. Roe - Brooke T. Mossman • \\ Karen M. Lounsbury
}

Published online: 9 April 2008

(C) The Author(s) 2008

\begin{abstract}
Oxidant stress plays a role in the pathogenesis of pulmonary diseases, including fibrotic lung disease and cancer. We previously found that hydrogen peroxide $\left(\mathrm{H}_{2} \mathrm{O}_{2}\right)$ initiates an increase in $\mathrm{Ca}^{2+} / \mathrm{cAMP}$-response element binding protein (CREB) phosphorylation in $\mathrm{C} 10$ alveolar type II cells that requires activation of extracellular regulated kinases 1/2 (ERK1/2). Here, we investigated the role of crosstalk between protein kinase A (PKA) and epidermal growth factor receptor (EGFR) in oxidant-induced signaling to ERK1/2 and CREB in C10 cells. Application of $\mathrm{H}_{2} \mathrm{O}_{2}$ increased nuclear accumulation of PKA, and inhibition of PKA with $\mathrm{H} 89$ reduced oxidant-mediated phosphorylation of both CREB and ERK1/2. Single cell measurements of cAMP and redox status, using a FRET-based biosensor and a redox-sensitive GFP, respectively, indicated that $\mathrm{H}_{2} \mathrm{O}_{2}$ increases production of cAMP that correlates with redox state. Inhibition of EGFR activity decreased both $\mathrm{H}_{2} \mathrm{O}_{2}$ induced CREB phosphorylation and translocation of PKA to the nucleus, suggesting that crosstalk between PKA and EGFR underlies the oxidant-induced CREB response.
\end{abstract}

C. A. Barlow · K. M. Lounsbury $(\bowtie)$

Department of Pharmacology, University of Vermont,

89 Beaumont Avenue, Burlington, VT 05405, USA

e-mail: Karen.Lounsbury@uvm.edu

Present Address:

C. A. Barlow

Department of Pharmacology, University of Wisconsin,

Madison, WI 53713, USA

K. Kitiphongspattana $\cdot$ N. Siddiqui $\cdot$ M. W. Roe

Department of Medicine, University of Chicago, Chicago,

IL 60637, USA

B. T. Mossman

Department of Pathology, University of Vermont, Burlington,

VT 05405 , USA
Furthermore, knockdown of CREB expression using siRNA led to a decrease in bcl-2 and an increase in oxidant-induced apoptosis. Together these data reveal a novel role for crosstalk between PKA, ERK1/2 and CREB that mediates cell survival during oxidant stress.

Keywords Pulmonary epithelium - Lung fibrosis .

Oxidative stress - FRET biosensor - Transcription factor
Abbreviations
CRE $\quad \mathrm{Ca}^{2+} / \mathrm{cAMP}$-response element
CBP300 CREB binding protein 300
CREB $\mathrm{Ca}^{2+} / \mathrm{cAMP}$-response element binding protein
EGFR Epidermal growth factor receptor
ERK1/2 Extracellular signal-regulated kinases 1/2
$\mathrm{H}_{2} \mathrm{O}_{2} \quad$ Hydrogen peroxide
GO Glucose oxidase
JNK c-Jun amino terminal kinase
MAPK Mitogen activated protein kinase
MEK Mitogen activated protein kinase kinase
PKA cAMP-dependent protein kinase
PKC Protein kinase C
ROS Reactive oxygen species
bcl-2 B-cell lymphoma-2
$\mathrm{TNF} \alpha \quad$ Tumor necrosis factor $\alpha$

\section{Introduction}

Lung epithelial cells, a target cell of inhaled oxidants, are subjected to a variety of environmental stresses, including oxidizing gases, particulates, and airborne microorganisms. Although the formation of oxidants is normally well regulated, excessive production may cause inflammation and cellular injury. Numerous studies suggest a role for oxidant 
stress in the pathogenesis of pulmonary diseases, including asthma, pulmonary fibrosis, and cancer [1].

Reactive oxygen species (ROS) are involved in multiple physiological processes through their capacity to regulate the expression of several growth factor receptors, protein kinases and phosphatases. In alveolar type II lung epithelial cells, hydrogen peroxide $\left(\mathrm{H}_{2} \mathrm{O}_{2}\right)$ induces tyrosine phosphorylation of the epidermal growth factor receptor (EGFR) [2] and leads to activation of protein kinase $\mathrm{C}$ (PKC) [3] and the mitogen activated protein kinases (MAPK) p38, c-Jun amino-terminal kinase (JNK), and extracellular signal-regulated kinase 1/2 (ERK1/2) [4, 5]. $\mathrm{H}_{2} \mathrm{O}_{2}$ also activates the expression of transcription factors, including $\mathrm{Ca}^{2+} /$ cyclic AMP-response element binding protein (CREB) [6] and members of the activator protein (AP-1) family, c-jun and c-fos [7], resulting in proliferation [4] and apoptosis [6, 8].

CREB is a $43 \mathrm{kDa}$ transcription factor belonging to the basic-leucine zipper (bZIP) family and is regulated by phosphorylation at serine residue 133 [9, 10]. Phosphorylation of CREB initiates recruitment of co-factors to the $\mathrm{Ca}^{2+} / \mathrm{cAMP}$-response element (CRE) that are necessary for transcriptional activation such as CREB-binding protein (CBP300) [11]. CREB activation is regulated by both $\mathrm{Ca}^{2+}$ and cAMP, which have been shown to regulate both ERK1/ 2- and protein kinase A (PKA)-mediated CREB phosphorylation $[6,12,13]$. Many genes important for regulation of proliferation and apoptosis, including $\mathrm{c}$-fos and bcl-2, respectively, contain CREs in their promoter [11].

Our previous studies have shown that exposure of alveolar type II cells to bolus $\mathrm{H}_{2} \mathrm{O}_{2}$ or asbestos fibers results in CREB activation that is dependent on ERK1/2 activation [6, 14]. Furthermore, we found that preventing CREB activation promoted cell survival and enhanced $b c l-2$ transcription, revealing a potential role for CREB in $\mathrm{H}_{2} \mathrm{O}_{2}$-mediated apoptosis [6]. Because of known crosstalk between PKA, ERK1/2, and CREB in many cell types and the dose-dependent effects of $\mathrm{H}_{2} \mathrm{O}_{2}$, the goal of this study was to determine their relative importance in oxidant-induced signaling. The effects of transient bolus $\mathrm{H}_{2} \mathrm{O}_{2}$ as well as a peroxide generating system were tested to represent a range of oxidant concentrations that lead to cell proliferation and/or apoptosis. The data support the hypothesis that PKA and EGFR are central regulators of oxidant-induced ERK1/2 and CREB activation and demonstrate a link between PKA, EGFR, and CREB in cell survival following exposure to $\mathrm{H}_{2} \mathrm{O}_{2}$ in alveolar type II cells.

\section{Materials and methods}

Cell culture and treatments

C10 cells, a contact-inhibited, non-transformed murine alveolar type II epithelial cell line [15], were grown in
CMRL 1066 medium supplemented with L-glutamine, penicillin/streptomycin, and $10 \%$ fetal bovine serum (FBS) (GIBCO BRL, Rockville, MD). Cells were grown to $90 \%$ confluence, and then complete medium was replaced with CMRL 1066 medium supplemented with L-glutamine, penicillin/streptomycin, and $0.5 \%$ FBS for $48 \mathrm{~h}$ before exposure to agents.

$\mathrm{H}_{2} \mathrm{O}_{2}$ (Sigma, St. Louis, MO) was added to the medium at concentrations from $100 \mu \mathrm{M}$ to $300 \mu \mathrm{M}$. Recombinant glucose oxidase $(\mathrm{GO} ; 5 \mathrm{mU} / \mathrm{ml}, 15 \mathrm{mU} / \mathrm{ml}$, or $30 \mathrm{mU} / \mathrm{ml}$ ) (Roche, Indianapolis, IN) was used to provide low level fluxes of $\mathrm{H}_{2} \mathrm{O}_{2}$ [16, 17]. Forskolin and epidermal growth factor (EGF) (Sigma, St. Louis, MO) (10 $\mu \mathrm{M}$ and $100 \mathrm{ng} / \mathrm{ml}$, respectively) were used as positive controls for induction of phospho-CREB and phospho-EGFR, respectively. Tumor necrosis factor $\alpha(\mathrm{TNF} \alpha)$ (Calbiochem, LaJolla, CA) was used at $0.1 \mu \mathrm{g} / \mathrm{ml}$ to induce apoptosis. Control cultures received medium without agents and were treated identically.

The ERK1/2 inhibitor, U0126 (10 $\mu \mathrm{M}$ for $30 \mathrm{~min}$ prior to treatment), the EGFR tyrosine kinase inhibitor, Tyrphostin AG1478 (10 $\mu \mathrm{M}$ for $1 \mathrm{~h}$ prior to treatment), and the antioxidant enzyme, catalase $(1000 \mathrm{U} / \mathrm{ml} 1 \mathrm{~h}$ prior to treatment) were obtained from Calbiochem. The PKA inhibitor, H89 (10 $\mu \mathrm{M}$ for $1 \mathrm{~h}$ pre-treatment) was obtained from Biomol (Plymouth Meeting, PA). $N$-acetyl-L-cysteine (NAC; $10 \mathrm{mM} 16 \mathrm{~h}$ prior to treatment) and DL-Buthionine- $(S, R)$-sulfoximine $(\mathrm{BSO} ; 10 \mu \mathrm{M} 16 \mathrm{~h}$ prior to treatment) were purchased from Sigma (St. Louis, MO).

\section{Western blot analysis}

After C10 cells were exposed to agents as described above, the cells were washed twice with cold PBS and collected in $4 \mathrm{X}$ sample buffer $(200 \mu \mathrm{M}$ Tris, $\mathrm{pH}$ 6.8, 4\% SDS, $4 \mathrm{mg} / \mathrm{ml}$ bromophenol blue, $0.04 \% \quad \beta$-mercaptoethanol, $40 \%$ glycerol, $2 \mu \mathrm{M}$ pyronin-Y). The amount of protein in each sample was determined using the RC/DC protein assay (Bio-Rad). About $30 \mu \mathrm{g}$ of protein was separated by a $10 \%$ SDS-PAGE and transferred to nitrocellulose. Western blots were performed as described previously [6] using antibodies specific to total and phosphorylated CREB (1:1000; rabbit polyclonal anti-CREB, Cell Signaling Technologies, Danvers, MA; 1:500; rabbit polyclonal anti-phosphoCREB, Cell Signaling Technologies), total and phosphorylated ERK1/2 (1:1000; rabbit polyclonal anti-ERK1/2, Cell Signaling Technologies; 1:500; rabbit polyclonal antiphospho-ERK1/2, Cell Signaling Technologies). Antibody binding was detected using horse radish peroxidase (HRP)conjugated anti-rabbit secondary antibody (1:5000; Jackson ImmunoResearch Laboratories, Inc., West grove, PA), followed by chemiluminescence (Kirkgaard and Perry Laboratories, Gaithersburg, MD). QuantityOne (Bio-Rad, 
Hercules, CA) was used to quantify band density, and intensity of phospho-CREB bands were normalized to the intensity of the corresponding total CREB bands.

Live cell imaging of cAMP and redox potential

C10 cells grown on glass coverslips in 6-well tissue culture dishes were transiently transfected with $8 \mu \mathrm{g}$ of a plasmid encoding a unimolecular fluoresecent resonance energy transfer (FRET)-based cAMP biosensor, Epac1-camps (provided by Dr. Martin Lohse, University of Würtzburg) $[18,19]$, or $1 \mu \mathrm{g}$ of a plasmid encoding a redox-sensitive green fluorescent protein (GFP), roGFP2 (a gift from Dr. James Remington, University of Oregon) [20], using Lipofectamine 2000 (Invitrogen, Carlsbad, CA), following the manufacturer's instructions. The transfection efficiency was approximately $50 \%$.

Imaging experiments were conducted after $48-72 \mathrm{~h}$ of transfection, and the growth medium removed and replaced with Krebs-Ringer bicarbonate solution (KRB; $119 \mathrm{mM}$ $\mathrm{NaCl}, 4.7 \mathrm{mM} \mathrm{KCl}, 2.5 \mathrm{mM} \mathrm{CaCl}_{2}, 1 \mathrm{mM} \mathrm{MgCl} 2,1 \mathrm{mM}$ $\mathrm{KH}_{2} \mathrm{PO}_{4}, 25 \mathrm{mM} \mathrm{NaHCO} 3$ or $10 \mathrm{mM}$ HEPES-NaOH $(\mathrm{pH}$ 7.40), and $2 \mathrm{mM}$ glucose). Coverslips were placed into a heated microperfusion chamber mounted on the specimen stage of an inverted fluorescence microscope (Nikon TE-2000U) equipped with a CARV spinning disk confocal system (Atto Bioscience Inc., Rockville, MD). Cells were continuously superfused with Krebs-Ringer bicarbonate solution $(2-5 \mathrm{ml} / \mathrm{min})$ at $37^{\circ} \mathrm{C}$. Dithiothreitol (DTT) (Calbiochem, LaJolla, CA) was used to calibrate the redox minimum.

For imaging Epac1-camps FRET and roGFP2, cells were visualized with a Nikon Super Fluor $40 \times$ objective. MetaFluor/MetaMorph software was used for image acquisition and analysis (Universal Imaging). The Epac1-camps EYFP excitation wavelength was $440 \mathrm{~nm}$. Dual emission ratio imaging at $485 \mathrm{~nm}$ and $535 \mathrm{~nm}$ for Epac1-camps and dual excitation ratio imaging at $400 \mathrm{~nm}$ and $490 \mathrm{~nm}$ for roGFP2 were accomplished using a computer-controlled high speed filter wheel (Lambda 10-2 optical filter changer with rotation every 60-80 ms, Sutter Instrument Co., Novato, CA). For roGFP2, a 505DRLP dichroic mirror and an emission filter, 535DF25, were used. Images (50-250 ms exposure) were captured every $10 \mathrm{~s}$ with a 16-bit Cascade 650 digital camera (Roper Instruments, Trenton, NJ) and background-corrected by manual selection of background regions [19].

The ratio values were normalized to the average baseline values measured 1-min prior to application $\mathrm{H}_{2} \mathrm{O}_{2}$. Epac1camps FRET decreases with increasing cAMP concentration, thus increased $[\mathrm{cAMP}]_{c}$ is correlated with an increase in the relative emission ratio of ECFP/EYFP (485/535) [18]. Data were thus expressed as relative ratio 485/535 for Epac1camps and fold increase in relative ratio 400/490 for roGFP2.
Immunofluorescence in $\mathrm{C} 10$ cells

C10 cells were grown on glass coverslips for all experiments. After experimental exposures, immunofluorescence to detect the catalytic subunit of PKA $\alpha$ was performed as previously described $[6,21]$. Briefly, cells were washed with phosphate buffered saline (PBS), fixed in $3.7 \%$ formaldehyde, permeablized with $-20^{\circ} \mathrm{C}$ methanol and incubated with blocking solution containing $2 \%$ bovine serum albumin (BSA) in PBS. Cells were incubated with primary antibody (1:100; rabbit polyclonal PKA $\alpha$ catalytic subunit antibody, Santa Cruz, Santa Cruz, CA) diluted in $2 \%$ BSA plus $0.1 \%$ Triton X-100 in PBS (BSA/PBS-T) overnight at $4^{\circ} \mathrm{C}$. Secondary antibody $(1: 400$; AlexaFlour 568 goat-anti-rabbit IgG, Molecular Probes) diluted in BSA/PBS-T was applied for $1 \mathrm{~h}$ at room temperature (RT), and followed by incubation with nuclear counterstain, YOYO-1 iodide (Molecular Probes, Carlsbad, CA; $1: 10,000), 1$ unit/ml RNase, and $0.1 \%$ sodium azide in BSA/PBS-T for $30 \mathrm{~min}$ at RT. Coverslips were mounted onto slides with AquaPolyMount (Polysciences, Inc. Warrington, PA). For each sample, confocal images were collected in fluorescence modes using a BioRad MRC1024ES confocal scanning laser microscope (Bio-Rad, Hercules, CA). For quantification, a nuclear mask was generated in Corel Photopaint using the YOYO-1 image template, and pixel intensities for PKA $\alpha$ were determined within the nuclear mask area as previously described [22].

Transient transfections with small interfering RNA (siRNA)

The siCONTROL non-targeting siRNA \#2 and SMARTpool mouse CREB siRNA (100 nM; Dharmacon, Lafayette, CO) were transfected into $\mathrm{C} 10$ cells using Lipofectamine 2000 (Invitrogen, Carlsbad, CA), following the manufacturer's instructions. After $4 \mathrm{~h}$ in transfection media, FBS was added to $10 \%$ and cells were incubated for $24 \mathrm{~h}$. Cells were then transferred to reduced serum media (0.5\% FBS) for $24 \mathrm{~h}$ prior to treatments.

\section{Real time quantitative PCR (RT qPCR)}

Total RNA was extracted from $\mathrm{C} 10$ cells using the RNeasy ${ }^{\mathrm{TM}}$ PLUS protocol for total RNA isolation from animal cells (Qiagen,Valencia, CA). cDNA was reverse transcribed from $500 \mathrm{ng}$ total RNA using an Omniscript ${ }^{\mathrm{TM}}$ Reverse Transcriptase RNase free DNase kit (Qiagen), with an oligo dT primer, according to the manufacturer's protocol. RT qPCR primers and probes for B-cell lymphoma-2 (bcl-2) and c-fos were obtained as Assays-onDemand $^{\mathrm{TM}}$ kits from Applied Biosystems (Foster City, 
CA). PCR products were detected by TaqMan qPCR, as previously described [23]. Expression levels of target genes were determined using hypoxanthine-guanine phosphoribosyl transferase (hprt) as the internal standard. Samples were run in duplicate from 3 independent experiments and the comparative $\mathrm{Ct}$ (cycle threshold) method for relative quantity (RQ value) was used to calculate relative mRNA expression among samples.

Detection and quantification of apoptosis

Apoptosis was detected by measuring single-stranded DNA using Apostain ${ }^{\mathrm{TM}}$ as previously described [24]. Briefly, cell monolayers grown on glass coverslips were treated with $30 \mathrm{mU} / \mathrm{ml} \mathrm{GO}$ for $24 \mathrm{~h}$, then fixed in methanol for $24 \mathrm{~h}$ at $-20^{\circ} \mathrm{C}$, boiled for $5 \mathrm{~min}$ in PBS containing $5 \mathrm{mM} \mathrm{MgCl}_{2}$, and then immersed in ice-cold PBS for $10 \mathrm{~min}$. Cells were blocked with $40 \%$ FBS and then incubated with Apostain F7-26 (Alexis Biochemicals, San Diego, CA, $10 \mu \mathrm{g} / \mathrm{ml}$ ) followed by HRP-conjugated secondary antibody (goat anti-mouse IgM; Jackson Labortories, West Grove, PA, 1:400). To visualize secondary antibody binding, the peroxidase substrate DAB (Sigma) was used. Coverslips were mounted onto slides with AquaPolyMount (Polysciences, Inc. Warrington, PA) for subsequent examination using bright field light microscopy. To determine the numbers of apoptotic cells and total cell numbers per field, 5 random fields were evaluated per experimental condition at x200 total magnification.

\section{Statistical analysis}

Statistical analyses were performed using non-normalized data, and pair-wise comparisons between treatment groups were achieved using Student's $t$-test or Mann-Whitney Rank Sum Test method for unequal variances. ANOVA (Holm-Sidak method) was used for multiple comparisons. Differences were considered statistically significant at $P<0.05$.

\section{Results}

CREB is phosphorylated after exposure to $\mathrm{H}_{2} \mathrm{O}_{2}$ and glucose oxidase

We have previously shown that $\mathrm{H}_{2} \mathrm{O}_{2}$ causes CREB phosphorylation in alveolar type II cells [6]. Here, we further show by Western blot that the CREB response to bolus addition of $\mathrm{H}_{2} \mathrm{O}_{2}$ (Fig. 1a) and $\mathrm{H}_{2} \mathrm{O}_{2}$ generated by glucose oxidase (GO) (Fig. 1b) is reduced when pretreated with the antioxidants NAC or catalase at effective concentrations documented previously in C10 cells [25].
A
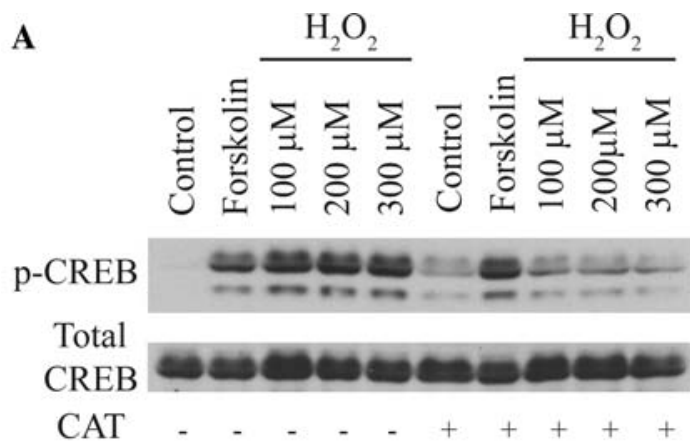

B
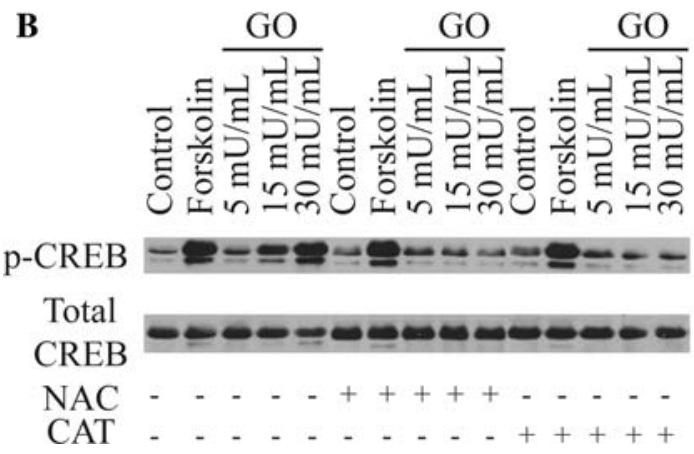

Fig. 1 Bolus and glucose oxidase generated $\mathrm{H}_{2} \mathrm{O}_{2}$ mediate CREB phosphorylation in an oxidant-dependent manner. (a) C10 cells, preincubated with $1,000 \mathrm{U} / \mathrm{ml}$ catalase (CAT) for $1 \mathrm{~h}$, were treated with $10 \mu \mathrm{M}$ forskolin or 100,200 , or $300 \mu \mathrm{M} \mathrm{H}_{2} \mathrm{O}_{2}$ for $10 \mathrm{~min}$, and then analyzed by Western blot analysis for phospho-CREB (p-CREB). (b) C10 cells, pre-incubated with $10 \mathrm{mM}$ NAC for $16 \mathrm{~h}$ or $1,000 \mathrm{U} / \mathrm{ml}$ catalase (CAT) for $1 \mathrm{~h}$, were treated with $10 \mu \mathrm{M}$ forskolin or 5,15 , or $30 \mathrm{mU} / \mathrm{ml}$ glucose oxidase (GO) for $4 \mathrm{~h}$, and then analyzed by Western blot analysis for phospho-CREB (p-CREB). An antibody recognizing total CREB was used as a control for protein loading in $A$ and $B$. Data are representative of 3 separate experiments

$\mathrm{H}_{2} \mathrm{O}_{2}$-induced CREB phosphorylation is decreased after the reduction of PKA activity

Because PKA is an important regulator of CREB [9], we investigated its role in $\mathrm{H}_{2} \mathrm{O}_{2}$-induced CREB phosphorylation. Cells were examined after exposure to lower concentrations previously associated with expression of cyclin $\mathrm{D}(100 \mu \mathrm{M})$ and higher concentrations known to induce apoptosis $(300 \mu \mathrm{M})[6,26]$. Exposure to $\mathrm{H}_{2} \mathrm{O}_{2}$ led to CREB phosphorylation in a concentration-dependent manner that was significantly decreased after reduction of PKA activity using the specific inhibitor H89 (Fig. 2a, b). The pattern of CREB phosphorylation in response to $\mathrm{H}_{2} \mathrm{O}_{2}$ closely paralleled that seen in response to activation of PKA by forskolin. $\mathrm{H} 89$ also reduced $\mathrm{H}_{2} \mathrm{O}_{2}$-mediated ERK1/2 activation, suggesting that PKA may regulate CREB activation directly or indirectly through ERK1/2mediated CREB activation.

Similar to results with bolus addition of $\mathrm{H}_{2} \mathrm{O}_{2}, \mathrm{H}_{2} \mathrm{O}_{2}$ generated by GO stimulated CREB phosphorylation in a dose-dependent manner and the phosphorylation was 

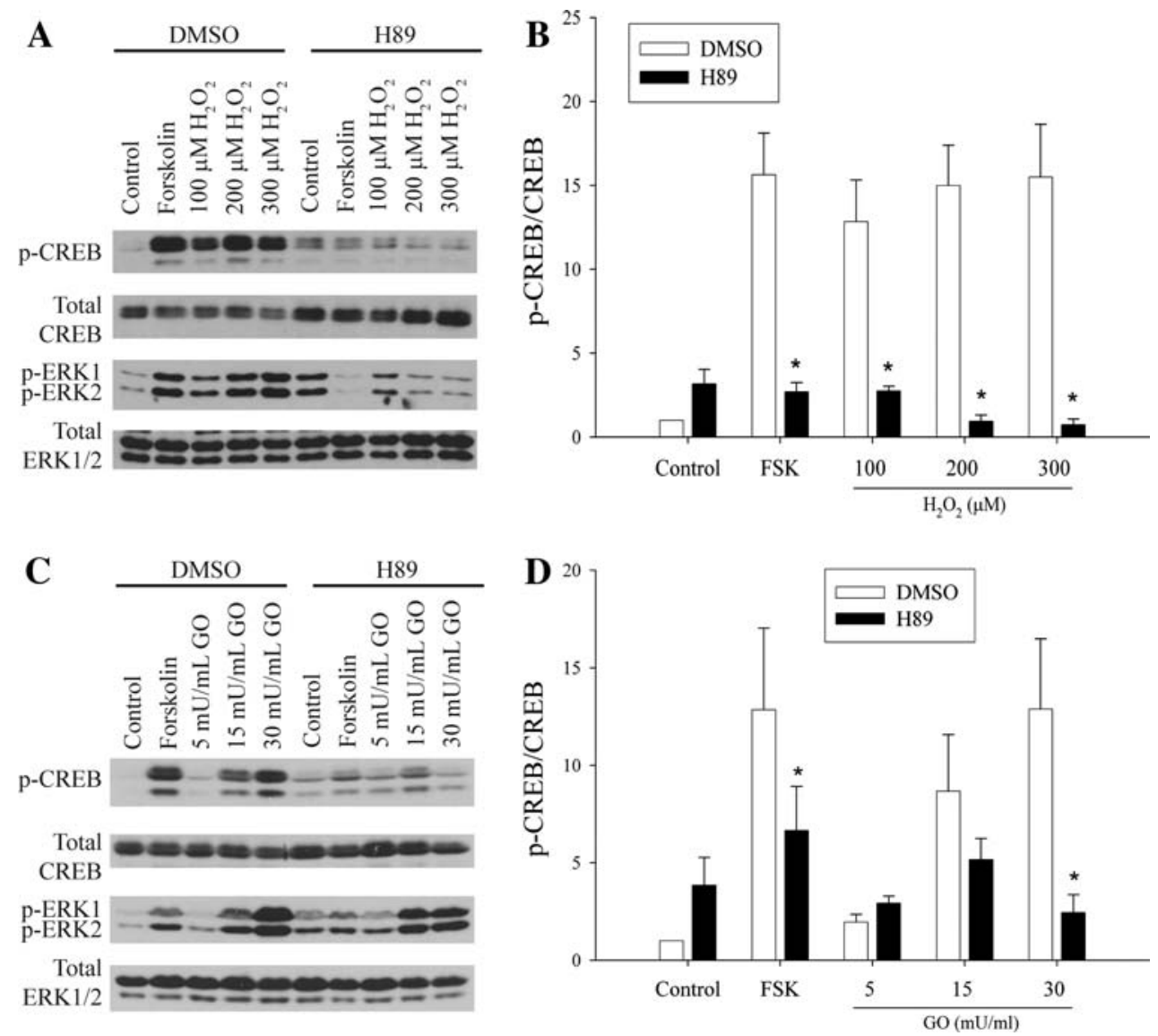

Fig. $2 \mathrm{H}_{2} \mathrm{O}_{2}$-mediated $\mathrm{CREB}$ activation is inhibited by the PKA inhibitor, H89. (a) $\mathrm{C} 10$ cells, pre-incubated with $10 \mu \mathrm{M} \mathrm{H} 89$ for $1 \mathrm{~h}$, were treated with $10 \mu \mathrm{M}$ forskolin or indicated concentrations of $\mathrm{H}_{2} \mathrm{O}_{2}$ for $10 \mathrm{~min}$, and then analyzed by Western blot analysis for phosphoCREB (p-CREB), total CREB, phospho-ERK1/2 (p-ERK1/2) and total ERK1/2. (b) Quantification of p-CREB band intensities from $A$ corrected using the corresponding CREB band intensity and normalized to the untreated control. Data represent 4 separate experiments; $* P<0.05$ when compared with corresponding condition without H89. (c) C10 cells, pre-incubated with $10 \mu \mathrm{MH} 89$ for $1 \mathrm{~h}$, were treated with $10 \mu \mathrm{M}$ forskolin or indicated concentrations of glucose oxidase (GO) for $4 \mathrm{~h}$, and then analyzed by Western blot for phosphoCREB (p-CREB), total CREB, phospho-ERK1/2 (p-ERK1/2), and total ERK1/2. (d) Quantification of p-CREB band intensities from $C$ corrected using the corresponding CREB band intensity and normalized to the untreated control. Data represent mean \pm SEM from 4 separate experiments; $* P<0.05$ when compared with corresponding condition without $\mathrm{H} 89$ significantly reduced by PKA inhibition at higher concentrations of GO (Fig. 2c, d). However, unlike bolus addition, $\mathrm{H}_{2} \mathrm{O}_{2}$ generated by GO led to a dose-dependent increase in ERK1/2 phosphorylation that was marginally sensitive to inhibition of PKA activity, suggesting that the duration of the stimulus may cause differences in signaling patterns.

\section{$\mathrm{H}_{2} \mathrm{O}_{2}$ stimulates cAMP production in $\mathrm{C} 10$ cells}

Single cell imaging was utilized to determine whether $\mathrm{H}_{2} \mathrm{O}_{2}$ exerts a direct effect on upstream regulation of PKA through production of cAMP. Epac1-camps, a FRET-based cAMP biosensor, was expressed in C10 cells. Epac1-camps senses changes in cytoplasmic cAMP levels $\left([\mathrm{cAMP}]_{c}\right)$ through a cAMP-dependent conformational change resulting in reduced FRET between ECFP (485 emission) and EYFP (535 emission) $[18,19]$. Exposure to $\mathrm{H}_{2} \mathrm{O}_{2}$ caused a monophasic increase in $[\mathrm{cAMP}]_{c}$ (Fig. 3a) that was comparable to the response elicited by direct activation of adenylyl cyclase with forskolin, but with a slower rise time (Fig. 3c). $\mathrm{H}_{2} \mathrm{O}_{2}$ generated by $\mathrm{GO}$ stimulated a rise in [cAMP] $]_{c}$ similar in magnitude to bolus addition of $\mathrm{H}_{2} \mathrm{O}_{2}$, but with a longer lag-time presumably due to the slower generation of oxidant (Fig. 3b).

Single cell imaging was also used to measure redox status and correlate cAMP levels with redox status. The redox sensitive GFP variant, roGFP2, was expressed in C10 cells. Oxidation is detected by roGFP through a change in GFP excitation from $400 \mathrm{~nm}$ and $490 \mathrm{~nm}$ [20]. The time course of $\mathrm{H}_{2} \mathrm{O}_{2}$-mediated cAMP production correlated well with the level of intracellular oxidation measured by roGFP2 (Fig. 4a). Upon removal of $\mathrm{H}_{2} \mathrm{O}_{2}$, the redox state returned to baseline approximately $36 \mathrm{~min}$ after the initial exposure (Fig. 4b). 

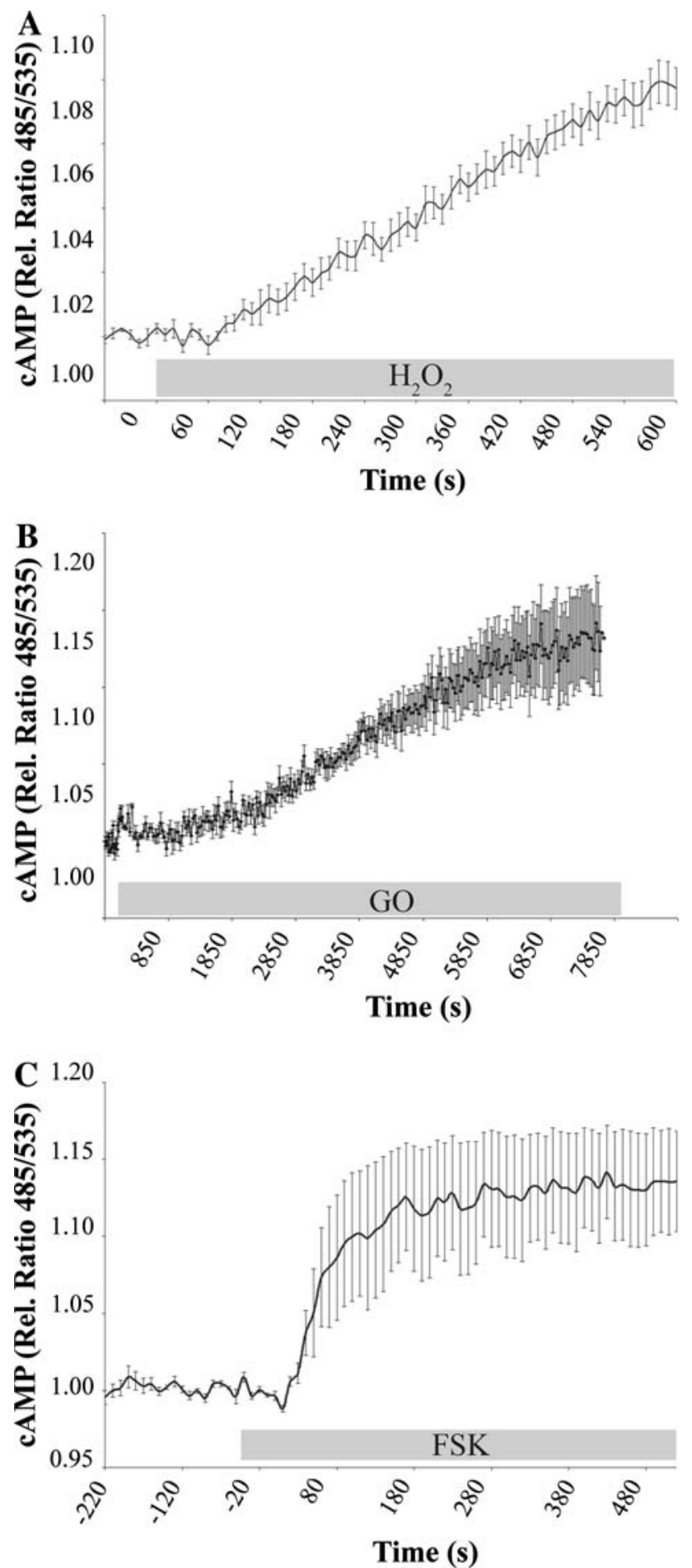

Fig. $3 \mathrm{H}_{2} \mathrm{O}_{2}$ stimulates an increase in cAMP levels. C10 cells were transiently transfected with the cAMP FRET indicator Epac1-camps and then exposed to $10 \mu \mathrm{M} 250 \mu \mathrm{M} \mathrm{H}_{2} \mathrm{O}_{2}$ (a), $15 \mathrm{mU} / \mathrm{ml}$ glucose oxidase (GO) (b), or $10 \mu \mathrm{M}$ forskolin (FSK) (c) for the times indicated. Data (means \pm SEM) are expressed as the relative ratio (485/535) of the cAMP response from the live emission recording of a representative cell. Grey bars indicate time of addition and length of exposure. Results are representative of $\geq 9,5$, and 4 cells $(A, B$ and $C$, respectively)
EGFR tyrosine kinase activity is important for signaling from $\mathrm{H}_{2} \mathrm{O}_{2}$ to PKA and CREB

It has been shown that the protein tyrosine activity of EGFR is important for EGF-mediated stimulation of adenylyl cyclase [27]. Thus to determine the contributions of EGFR in the observed $\mathrm{H}_{2} \mathrm{O}_{2}$-induced CREB phosphorylation, cells were evaluated with or without pretreatment with the specific EGFR tyrosine kinase inhibitor, AG1478. Application of AG1478 significantly reduced CREB phosphorylation in response to bolus addition $\mathrm{H}_{2} \mathrm{O}_{2}$ and to $\mathrm{H}_{2} \mathrm{O}_{2}$ generated by higher concentrations of GO (Fig. 5), suggesting that EGFR activity is involved in $\mathrm{H}_{2} \mathrm{O}_{2}$-induced CREB phosphorylation. As expected, reduction of EGFR activity also inhibited $\mathrm{H}_{2} \mathrm{O}_{2}$-induced ERK phosphorylation (Fig. 5).

Immunofluorescence evaluation of activated PKA translocation to the nucleus was used to more directly test the effects of $\mathrm{H}_{2} \mathrm{O}_{2}$ on PKA activation and to further evaluate a role for EGFR. Exposure to $\mathrm{H}_{2} \mathrm{O}_{2}$ led to an increase in the PKA free catalytic subunit that was significant in the nucleus at $300 \mu \mathrm{M}$ and similar to the response to forskolin. Inhibition of EGFR tyrosine kinase activity with AG1478 prevented the $\mathrm{H}_{2} \mathrm{O}_{2}$-induced increases at both $200 \mu \mathrm{M}$ and $300 \mu \mathrm{M}$ (Fig. 6).

Direct activation of CREB by PKA is a minor pathway in EGF-induced CREB phosphorylation

Because of the known crosstalk between EGFR, ERK1/2, and PKA, we examined the role of PKA and ERK1/2 in forskolinand EGF-induced CREB activation. Treatment with both forskolin and EGF resulted in a significant increase in CREB phosphorylation when compared to control cells (Fig. 7). Inhibition of PKA activity with H89 significantly decreased forskolin-induced CREB phosphorylation, but only blunted EGF-induced CREB phosphorylation. Inhibition of ERK1/2 phosphorylation with the MEK inhibitor, U0126, also considerably decreased CREB phosphorylation. The inhibitory effects of H89 and U0126 were not additive towards either forskolin- or EGF-induced CREB phosphorylation, suggesting that direct activation of CREB through PKA may play a minor role in the activation of CREB. Furthermore, both forskolin and EGF induced ERK1/2 phosphorylation, but only forskolin-mediated CREB phosphorylation was inhibited by $\mathrm{H} 89$, suggesting that PKA regulates CREB indirectly through the MAPK/ERK1/2 pathway.

Knockdown of CREB using siRNA results in loss of oxidant-induced c-fos and bcl-2 transcription

To more directly assess the role of CREB in oxidant-mediated responses, an siRNA approach was used to reduce levels of CREB within C10 cells. Transfection with siCREB resulted 


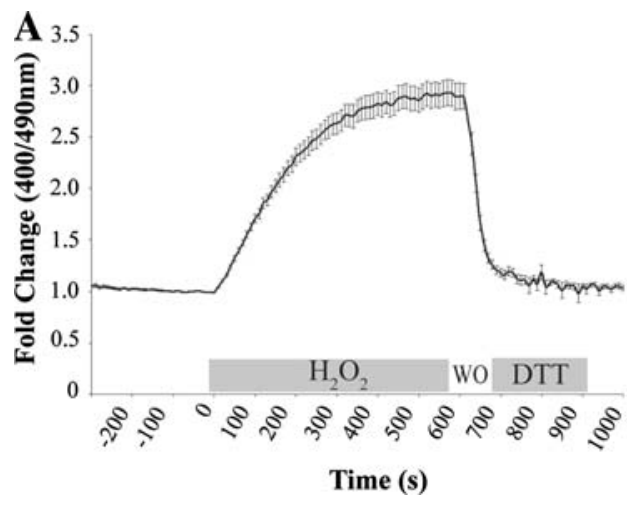

Fig. 4 Redox status correlates with cAMP level in cells responding to $\mathrm{H}_{2} \mathrm{O}_{2}$. C10 cells were transiently transfected with the redox indicator, roGFP2 and then exposed to $250 \mu \mathrm{M} \mathrm{H}_{2} \mathrm{O}_{2}$ for 10 min followed by $1 \mathrm{mM}$ DTT (a) or $15 \mathrm{mU} / \mathrm{ml}$ glucose oxidase (GO) for $65 \mathrm{~min}$, followed by $200 \mu \mathrm{M} \mathrm{H} \mathrm{H}_{2} \mathrm{O}_{2}$, and then $10 \mathrm{mM}$ DTT (b). Data

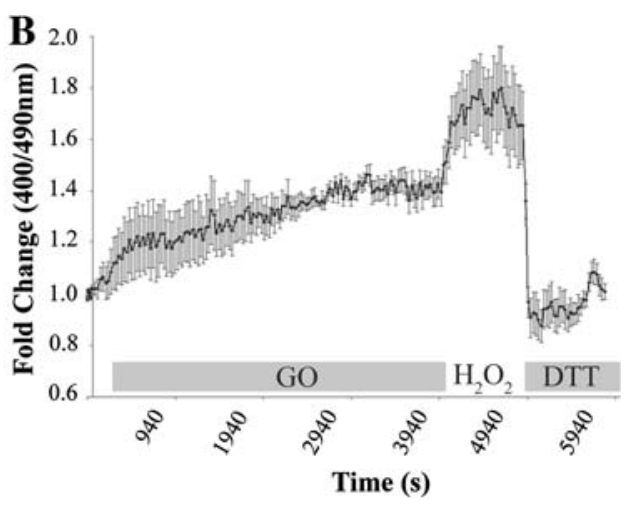

(means \pm SEM) are expressed as the fold change in the excitation ratio at $400 / 490 \mathrm{~nm}$ normalized to the average base-line ratio values measured 1 min before stimulation. Results are averages of $\geq 23$ and 11 cells ( $A$ and $B$, respectively). Grey bars indicate time of addition and length of exposure, and WO indicates wash out with KREBs buffer
Fig. 5 Reduction of EGFR tyrosine kinase activity leads to the inhibition of both $\mathrm{H}_{2} \mathrm{O}_{2-}$ induced CREB and ERK1/2. C10 cells, pre-incubated with the EGFR tyrosine kinase inhibitor AG1478 $(10 \mu \mathrm{M})$ for $1 \mathrm{~h}$, were treated with $10 \mu \mathrm{M}$ forskolin or $100 \mathrm{ng} / \mathrm{ml} \mathrm{EGF}$ for $5 \mathrm{~min}$, the indicated concentrations of $\mathrm{H}_{2} \mathrm{O}_{2}$ for 10 min (a) or glucose oxidase (GO) for $4 \mathrm{~h} \mathrm{(c),} \mathrm{and} \mathrm{then}$ analyzed by Western blot analysis for phospho-CREB (p-CREB), total CREB, phospho-ERK1/2 (p-ERK1/2), and total ERK1/2. (b, d) Quantification of p-CREB band intensities from $A$ and $C$ respectively corrected using the corresponding CREB band intensity and normalized to the untreated control. Data represent mean \pm SEM of 3 separate experiments; $* P<0.05$ when compared with corresponding condition without AG1478
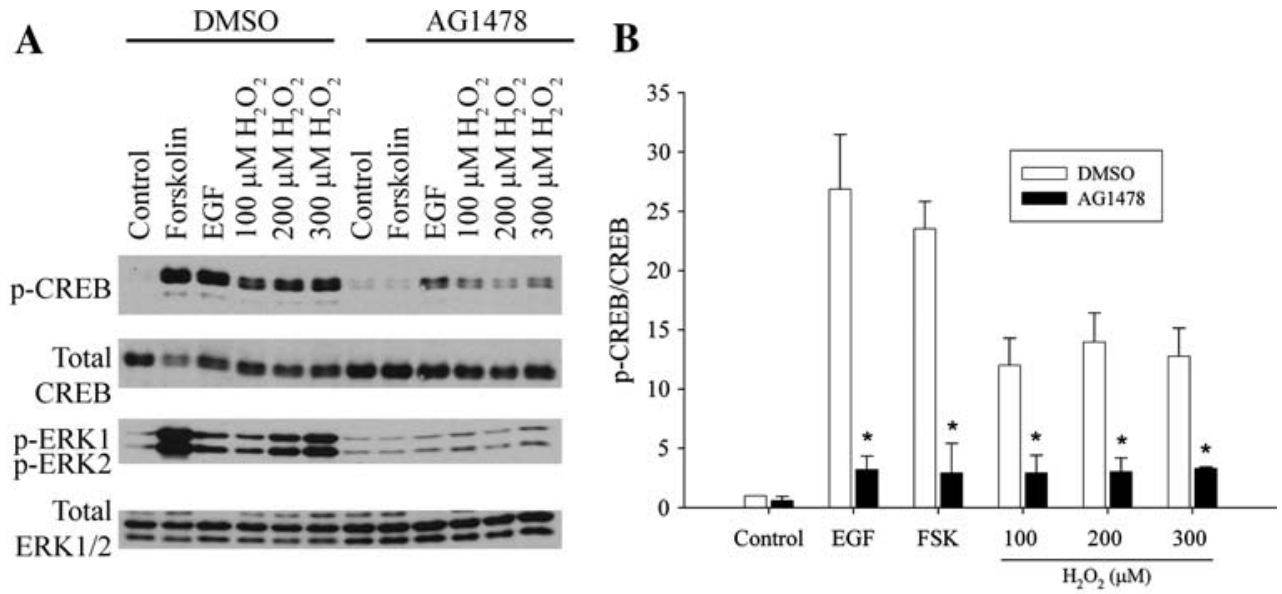

C

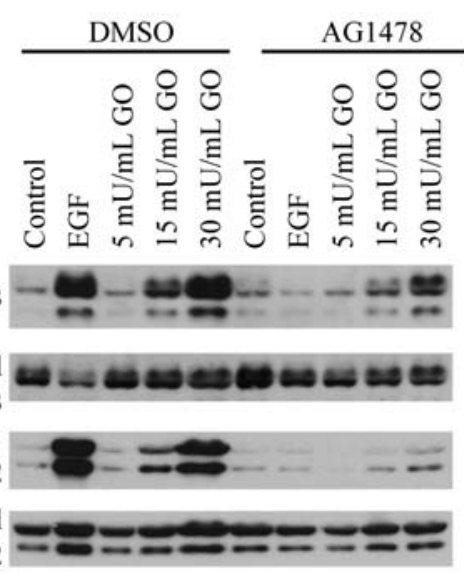

D

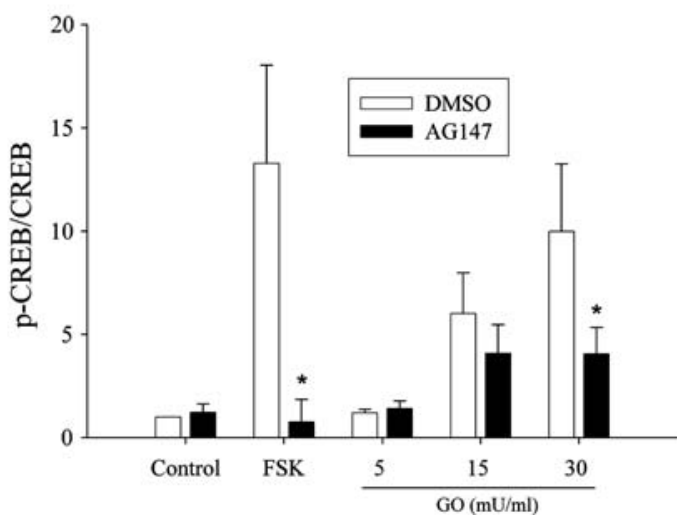

in greater than $80 \%$ knockdown of both CREB mRNA and protein levels (Fig. 8a, b). CRE-containing genes previously shown to be upregulated by $\mathrm{H}_{2} \mathrm{O}_{2}$ including bcl-2 and c-fos were found to be dose-dependently induced by GO. Induction was significantly reduced in cells transfected with siCREB (Fig. 8c, d), suggesting that CREB is essential for the transcriptional response of these genes to $\mathrm{H}_{2} \mathrm{O}_{2}$.
Knockdown of CREB significantly increases the number of cells undergoing apoptosis following exposure to glucose oxidase

Recently, we have shown that reduction of CREB activity, by introducing a phosphorylation-null CREB construct, led to a decrease in apoptosis [6]. To resolve whether CREB is 

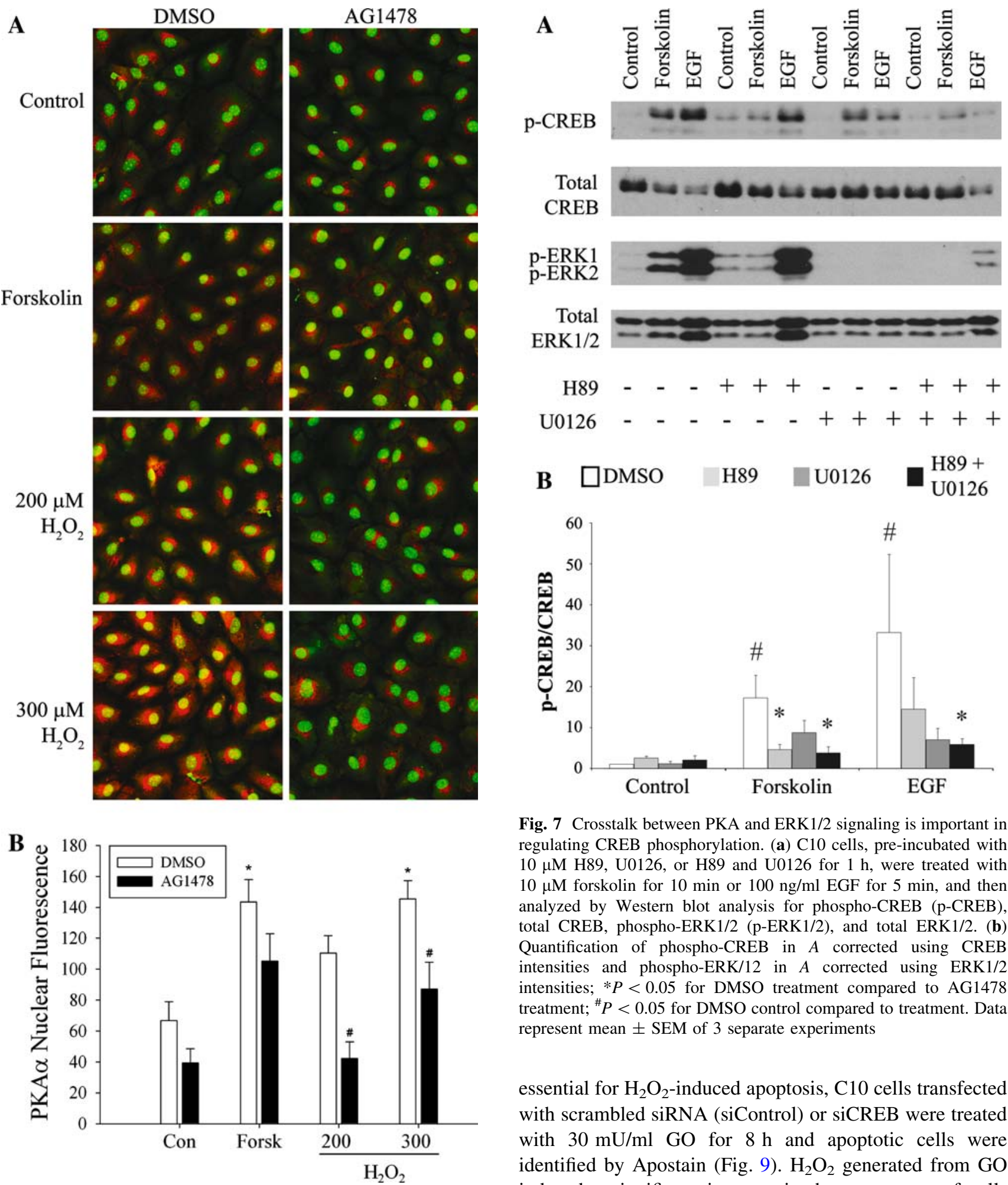

Fig. 7 Crosstalk between PKA and ERK1/2 signaling is important in regulating CREB phosphorylation. (a) C10 cells, pre-incubated with $10 \mu \mathrm{M} \mathrm{H} 89$, U0126, or H89 and U0126 for $1 \mathrm{~h}$, were treated with $10 \mu \mathrm{M}$ forskolin for $10 \mathrm{~min}$ or $100 \mathrm{ng} / \mathrm{ml} \mathrm{EGF}$ for $5 \mathrm{~min}$, and then analyzed by Western blot analysis for phospho-CREB (p-CREB), total CREB, phospho-ERK1/2 (p-ERK1/2), and total ERK1/2. (b) Quantification of phospho-CREB in $A$ corrected using CREB intensities and phospho-ERK/12 in $A$ corrected using ERK1/2 intensities; $* P<0.05$ for DMSO treatment compared to AG1478 treatment; ${ }^{\#} P<0.05$ for DMSO control compared to treatment. Data represent mean \pm SEM of 3 separate experiments

essential for $\mathrm{H}_{2} \mathrm{O}_{2}$-induced apoptosis, $\mathrm{C} 10$ cells transfected with scrambled siRNA (siControl) or siCREB were treated with $30 \mathrm{mU} / \mathrm{ml} \mathrm{GO}$ for $8 \mathrm{~h}$ and apoptotic cells were identified by Apostain (Fig. 9). $\mathrm{H}_{2} \mathrm{O}_{2}$ generated from GO induced a significant increase in the percentage of cells undergoing apoptosis compared to the control in both siControl and siCREB cells. Cells expressing siCREB had significantly higher levels of apoptosis than the siControl cells in both the untreated condition and after GO exposure, supporting a role for CREB in the regulation of apoptosis induced by $\mathrm{H}_{2} \mathrm{O}_{2}$. Interestingly, the apoptotic 
Fig. 8 Knockdown of CREB using siRNA results in loss of oxidantinduced c-fos and bcl-2 transcription. (a) C10 cells were transfected with $100 \mathrm{nM}$ scrambled siRNA (siControl) or siCREB followed by Western blot analysis to detect CREB. $\beta$-actin was used as a loading control. (b) Cells were transfected as in $A$, followed by treatment with 5 or $15 \mathrm{mU} / \mathrm{ml}$ glucose oxidase (GO) for $6 \mathrm{~h}$. Total RNA was extracted and cDNA was assessed by RT qPCR to quantify CREB, bcl-2 and c-fos mRNA levels. Shown are relative quantity (RQ) values normalized to the siControl sample. ${ }^{\#} P<0.05$ when compared to untreated siCon; $* P<0.05$ when compared to treatment siCon

enhancing effect was not selective for $\mathrm{H}_{2} \mathrm{O}_{2}$-mediated apoptosis, as siCREB also enhanced the apoptotic effect of TNF $\alpha$. Taken together, these results suggest that CREB plays an important role in the cellular response to oxidant stress including upregulation of survival genes and promoting cell survival.

\section{Discussion}

Exposure to various environmental stresses, such as oxidative gases, metals, and particulates, initiates multiple physiological processes in alveolar type II cells. Oxidants have been implicated in the pathogenesis of lung cancer, pulmonary fibrosis, and asthma through their capacity to regulate an intricate network of protein kinases. Yet the relationship between oxidants and the pathogenesis of lung disease is unclear, primarily because of the lack of understanding of the mechanisms by which oxidants function in both normal physiological and disease states. In this study, we show for the first time that $\mathrm{H}_{2} \mathrm{O}_{2}$ exposure leads to an increase in cytoplasmic cAMP levels, followed by PKA-dependent CREB and ERK1/2 phosphorylation in alveolar type II cells. Furthermore, we show that EGFR activity is necessary for $\mathrm{H}_{2} \mathrm{O}_{2}$-stimulated nuclear accumulation of activated PKA and for PKA-mediated CREB phosphorylation. Together these data suggest that PKA is a central hub for interplay between EGFR, ERK1/2, and CREB signaling pathways activated by oxidant stress.

Several studies have shown crosstalk between PKA and ERK1/2 signaling pathways. This crosstalk appears to be cell type specific, since an increase in cAMP-dependent PKA activation stimulates ERK1/2 in some cells, but suppresses it in others [28-30]. We have previously demonstrated that $\mathrm{H}_{2} \mathrm{O}_{2}$ exposure leads to ERK1/2-dependent CREB phosphorylation in C10 alveolar type II cells [6]. Studies here have dissected the underlying mechanisms to reveal that $\mathrm{H}_{2} \mathrm{O}_{2}$-induces cAMP formation and PKA activation that are important for both ERK1/2 and CREB phosphorylation.

EGFR is overexpressed and activated in response to epithelial injury [31]. Its activation is believed to play an integral role in the cellular responses of lung epithelium to injury and oxidant stress, possibly by signal amplification
A

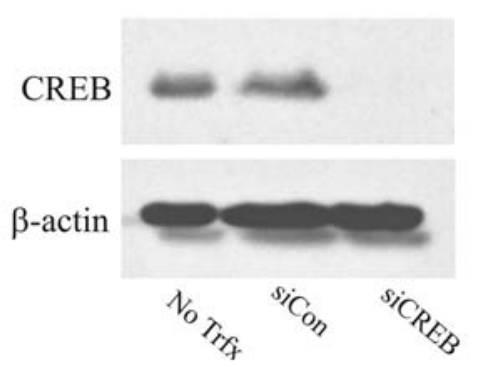

B
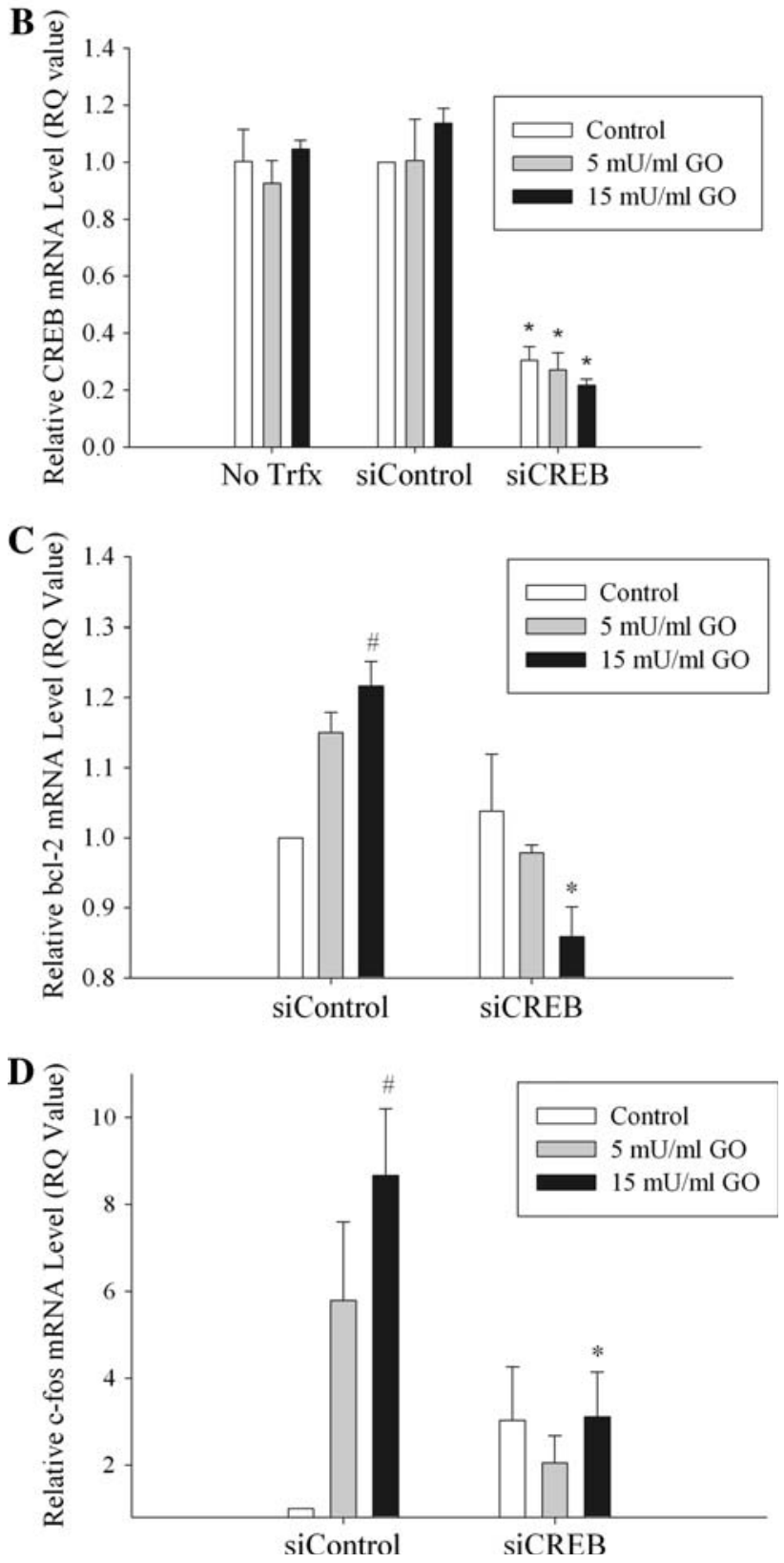

through MAPK phosphorylation cascades. Oxidative modification of a reduced cysteine residue in the EGFR reversibly affects its activation [32, 33]. Moreover, Goldkorn and colleagues have shown that in alveolar type II cells, $\mathrm{H}_{2} \mathrm{O}_{2}$ induces EGFR phosphorylation on tyrosine 
Fig. 9 CREB is protective against oxidant-induced apoptosis. (a) C10 cells, transfected with siControl or siCREB, were exposed to $30 \mathrm{mU} / \mathrm{ml}$ glucose oxidase (GO) or $0.1 \mu \mathrm{g} / \mathrm{ml}$ tumor necrosis factor $\alpha(\mathrm{TNF} \alpha)$ for $8 \mathrm{~h}$ followed by identification of apoptotic cells using Apostain. (b) Quantification of \% Apostain positive cells was determined by scoring the average of 5 fields/condition; $* P<0.05$ when compared to untreated siCon; ${ }^{\#} P<0.05$ when compared to treatment siCon. Data represent mean \pm SEM of 4 separate experiments. Bar $=100 \mu \mathrm{m}$
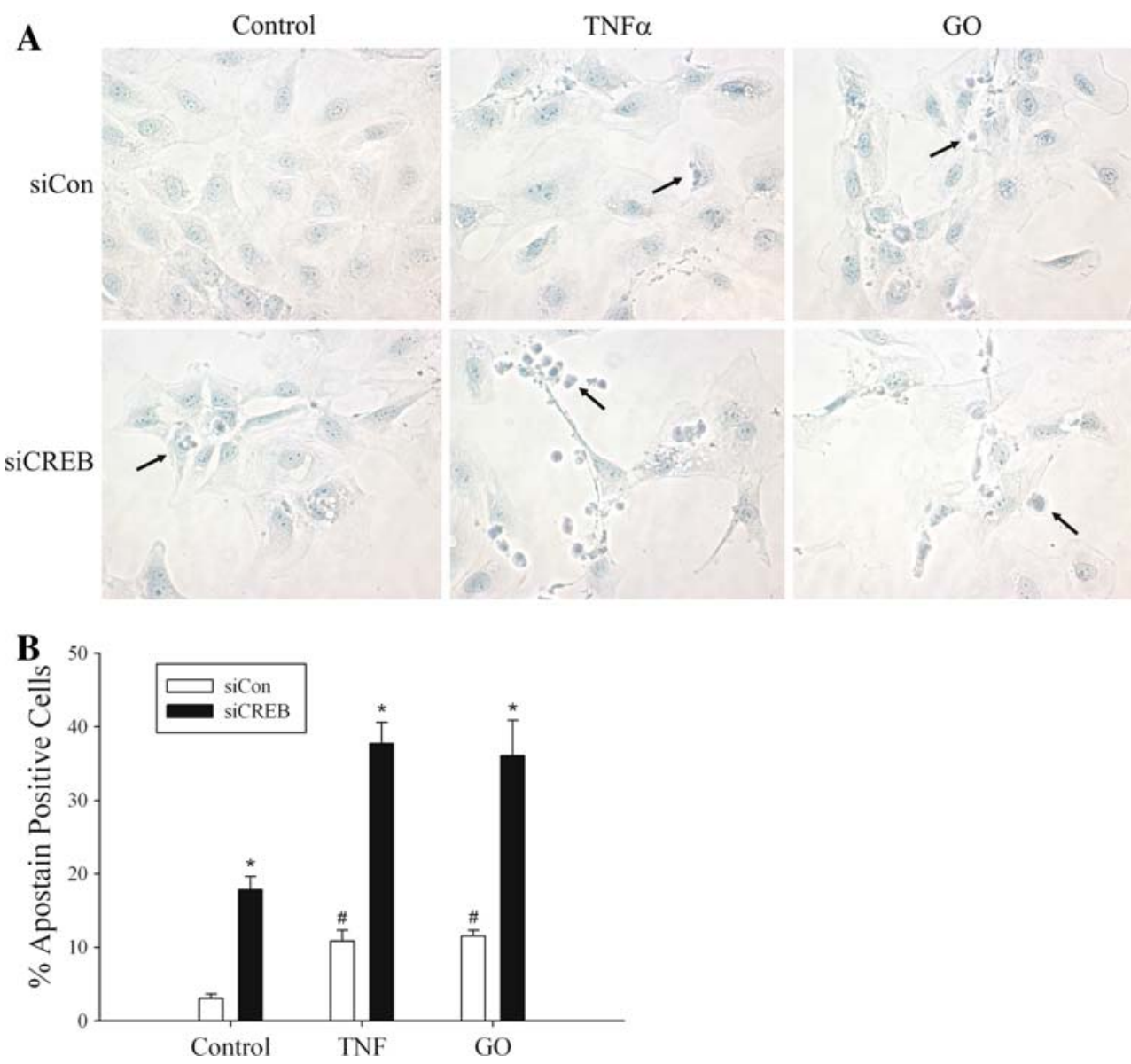

residues [2]. These findings suggest that even though there is no specific receptor for oxidants, their signaling may be efficiently transduced through interactions with the EGFR.

In the present study, we show that EGFR activity is necessary for both activation of PKA nuclear translocation and subsequent $\mathrm{CREB}$ phosphorylation in response to $\mathrm{H}_{2} \mathrm{O}_{2}$. Mitogenic signals transmitted through the EGFR have been shown to involve PKA-dependent signaling cascades. Tyrosine phosphorylation of the EGFR requires an increase in cAMP levels and PKA function in many, but not all cell types [34, 35]. In addition, tyrosine kinase activity of EGFR is required for growth factor stimulation of adenylyl cyclase activity, which leads to the activation of PKA [27, 36]. PKA activity has also been shown to promote downstream Raf-1 function and subsequent ERK activation [37]. Crosstalk has also been seen from EGFR to adenylyl cyclase activity and PKA in airway epithelial cells via beta adrenergic receptors [38, 39]. Thus, communication between EGFR and PKA is potentially bi-directional.

The $\mathrm{H}_{2} \mathrm{O}_{2}$-mediated generation of cAMP and the CREB activation response to $\mathrm{H}_{2} \mathrm{O}_{2}$ increased with oxidant concentration but, with minor exception, were not dependent on whether oxidant was added by bolus or generated by glucose/glucose oxidase. Although reduction of the CREB response by PKA or EGFR inhibition was only significant for the higher oxidant concentrations, a trend was observed with lower concentrations. While it is difficult to accurately predict the physiological significance of these oxidant levels, when put in context with previous findings, these observations suggest that CREB signaling through PKA and EGFR could participate in signaling that affects both oxidant-mediated proliferation and apoptosis.

Previously we demonstrated that expression of phosphorylation-incompetent CREB paradoxically increases bcl-2 transcription and reduces apoptosis following bolus $\mathrm{H}_{2} \mathrm{O}_{2}$ exposure [6]. Findings here show that siRNA-mediated knockdown of CREB results in a loss of bcl-2 mRNA and an increase in apoptosis in cells responding to an $\mathrm{H}_{2} \mathrm{O}_{2}$ generating system. The difference is likely due to the method of CREB inhibition, in that the dominant-negative CREB may have altered chromatin interactions with other transcription factors or caused quenching of the response. Putting these results in context with the findings of others, we propose that $\mathrm{CREB}$ activation through PKA signaling serves as a key survival pathway in cells responding to oxidant stress. PKA-and CREB-mediated gene expression may thus be important in regulating oxidant-mediated apoptosis resulting from lung pathologies, and future 
experiments will explore the importance of these signaling pathways in promoting changes in gene expression following lung epithelial cell injury or oxidant exposure.

Acknowledgements We thank Arti Shukla for her helpful discussions and editorial comments and Douglas Taatjes, Ph.D. from the UVM Cell Imaging and Analysis Core for technical assistance. This work was supported by National Institute of Health Grants PO1 HL67004 (KML), DK68822 (MWR) and DK64162 (MWR) with additional support from the Totman Medical Research Trust Fund (KML). CAB was supported by Environmental Pathology Training Grant NIEHS T3207122.

Open Access This article is distributed under the terms of the Creative Commons Attribution Noncommercial License which permits any noncommercial use, distribution, and reproduction in any medium, provided the original author(s) and source are credited.

\section{References}

1. Mossman BT, Churg A (1998) Mechanisms in the pathogenesis of asbestosis and silicosis. Am J Respir Crit Care Med 157:1666-1680

2. Goldkorn T, Balaban N, Matsukuma K, Chea V, Gould R, Last J, Chan C, Chavez C (1998) EGF-Receptor phosphorylation and signaling are targeted by $\mathrm{H} 2 \mathrm{O} 2$ redox stress. Am J Respir Cell Mol Biol 19:786-798

3. Konishi H, Tanaka M, Takemura Y, Matsuzaki H, Ono Y, Kikkawa U, Nishizuka Y (1997) Activation of protein kinase C by tyrosine phosphorylation in response to $\mathrm{H} 2 \mathrm{O} 2$. Proc Natl Acad Sci USA 94:11233-11237

4. Buder-Hoffmann S, Palmer C, Vacek P, Taatjes D, Mossman B (2001) Different accumulation of activated extracellular signalregulated kinases (ERK 1/2) and role in cell-cycle alterations by epidermal growth factor, hydrogen peroxide, or asbestos in pulmonary epithelial cells. Am J Respir Cell Mol Biol 24:405-413

5. Ishikawa Y, Kitamura M (2000) Anti-apoptotic effect of quercetin: intervention in the JNK- and ERK-mediated apoptotic pathways. Kidney Int 58:1078-1087

6. Barlow CA, Shukla A, Mossman BT, Lounsbury KM (2006) Oxidant-mediated cAMP response element binding protein activation: calcium regulation and role in apoptosis of lung epithelial cells. Am J Respir Cell Mol Biol 34:7-14

7. Janssen YM, Matalon S, Mossman BT (1997) Differential induction of c-fos, c-jun, and apoptosis in lung epithelial cells exposed to ROS or RNS. Am J Physiol 273:L789-L796

8. Jimenez LA, Zanella C, Fung H, Janssen YM, Vacek P, Charland C, Goldberg J, Mossman BT (1997) Role of extracellular signalregulated protein kinases in apoptosis by asbestos and $\mathrm{H} 2 \mathrm{O} 2$. Am J Physiol 273:L1029-L1035

9. Shaywitz AJ, Greenberg ME (1999) CREB: a stimulus-induced transcription factor activated by a diverse array of extracellular signals. Annu Rev Biochem 68:821-861

10. Lonze BE, Ginty DD (2002) Function and regulation of CREB family transcription factors in the nervous system. Neuron 35:605-623

11. Mayr B, Montminy M (2001) Transcriptional regulation by the phosphorylation-dependent factor CREB. Nat Rev Mol Cell Biol 2:599-609

12. Rosen LB, Ginty DD, Weber MJ, Greenberg ME (1994) Membrane depolarization and calcium influx stimulate MEK and MAP kinase via activation of Ras. Neuron 12:1207-1221

13. Taylor SS, Kim C, Vigil D, Haste NM, Yang J, Wu J, Anand GS (2005) Dynamics of signaling by PKA. Biochim Biophys Acta 1754:25-37
14. Barlow CA, Barrett TF, Shukla A, Mossman BT, Lounsbury KM (2007) Asbestos-mediated CREB phosphorylation is regulated by protein kinase A and extracellular signal-regulated kinases 1/2. Am J Physiol Lung Cell Mol Physiol 292:L1361-L1369

15. Malkinson AM, Dwyer-Nield LD, Rice PL, Dinsdale D (1997) Mouse lung epithelial cell lines-tools for the study of differentiation and the neoplastic phenotype. Toxicology 123:53-100

16. Burch PM, Yuan Z, Loonen A, Heintz NH (2004) An extracellular signal-regulated kinase 1- and 2-dependent program of chromatin trafficking of c-Fos and Fra-1 is required for cyclin D1 expression during cell cycle reentry. Mol Cell Biol 24:4696-4709

17. McElhinney B, Poynter ME, Shrivastava P, Hazen SL, JanssenHeininger YM (2003) Eosinophil peroxidase catalyzes JNKmediated membrane blebbing in a Rho kinase-dependent manner. J Leukoc Biol 74:897-907

18. Nikolaev VO, Bunemann M, Hein L, Hannawacker A, Lohse MJ (2004) Novel single chain cAMP sensors for receptor-induced signal propagation. J Biol Chem 279:37215-37218

19. Landa LR Jr, Harbeck M, Kaihara K, Chepurny O, Kitiphongspattana K, Graf O, Nikolaev VO, Lohse MJ, Holz GG, Roe MW (2005) Interplay of $\mathrm{Ca} 2+$ and cAMP signaling in the insulinsecreting MIN6 beta-cell line. J Biol Chem 280:31294-31302

20. Dooley CT, Dore TM, Hanson GT, Jackson WC, Remington SJ, Tsien RY (2004) Imaging dynamic redox changes in mammalian cells with green fluorescent protein indicators. J Biol Chem 279:22284-22293

21. Stevenson AS, Cartin L, Wellman TL, Dick MH, Nelson MT, Lounsbury KM (2001) Membrane depolarization mediates phosphorylation and nuclear translocation of CREB in vascular smooth muscle cells. Exp Cell Res 263:118-130

22. Wellman TL, Jenkins J, Penar PL, Tranmer B, Zahr R, Lounsbury KM (2004) Nitric oxide and reactive oxygen species exert opposing effects on the stability of hypoxia-inducible factor-1alpha (HIF-1alpha) in explants of human pial arteries. FASEB J 18:379-381

23. Pulver-Kaste RA, Barlow CA, Bond J, Watson A, Penar PL, Tranmer B, Lounsbury KM (2006) Ca2+ source-dependent transcription of CRE-containing genes in vascular smooth muscle. Am J Physiol Heart Circ Physiol 291:H97-H105

24. Shukla A, Stern M, Lounsbury KM, Flanders T, Mossman BT (2003) Asbestos-induced apoptosis is protein kinase C deltadependent. Am J Respir Cell Mol Biol 29:198-205

25. Shukla A, Flanders T, Lounsbury KM, Mossman BT (2004) The gamma-glutamylcysteine synthetase and glutathione regulate asbestos-induced expression of activator protein-1 family members and activity. Cancer Res 64:7780-7786

26. Phalen TJ, Weirather K, Deming PB, Anathy V, Howe AK, van der Vliet A, Jonsson TJ, Poole LB, Heintz NH (2006) Oxidation state governs structural transitions in peroxiredoxin II that correlate with cell cycle arrest and recovery. J Cell Biol 175:779-789

27. Nair BG, Patel TB (1993) Regulation of cardiac adenylyl cyclase by epidermal growth factor (EGF). Role of EGF receptor protein tyrosine kinase activity. Biochem Pharmacol 46:1239-1245

28. Impey S, Obrietan K, Wong ST, Poser S, Yano S, Wayman G, Deloulme JC, Chan G, Storm DR (1998) Cross talk between ERK and PKA is required for Ca2+ stimulation of CREB-dependent transcription and ERK nuclear translocation. Neuron 21:869-883

29. Dumaz N, Light Y, Marais R (2002) Cyclic AMP blocks cell growth through Raf-1-dependent and Raf-1-independent mechanisms. Mol Cell Biol 22:3717-3728

30. Yamaguchi T, Nagao S, Wallace DP, Belibi FA, Cowley BD, Pelling JC, Grantham JJ (2003) Cyclic AMP activates B-Raf and ERK in cyst epithelial cells from autosomal-dominant polycystic kidneys. Kidney Int 63:1983-1994

31. Van Winkle LS, Isaac JM, Plopper CG (1997) Distribution of epidermal growth factor receptor and ligands during bronchiolar 
epithelial repair from naphthalene-induced Clara cell injury in the mouse. Am J Pathol 151:443-459

32. Clark S, Konstantopoulos N (1993) Sulphydryl agents modulate insulin- and epidermal growth factor (EGF)-receptor kinase via reaction with intracellular receptor domains: differential effects on basal versus activated receptors. Biochem J 292(Pt 1):217-223

33. Woltjer RL, Staros JV (1997) Effects of sulfhydryl modification reagents on the kinase activity of the epidermal growth factor receptor. Biochemistry 36:9911-9916

34. Piiper A, Dikic I, Lutz MP, Leser J, Kronenberger B, Elez R, Cramer H, Muller-Esterl W, Zeuzem S (2002) Cyclic AMP induces transactivation of the receptors for epidermal growth factor and nerve growth factor, thereby modulating activation of MAP kinase, Akt, and neurite outgrowth in PC12 cells. J Biol Chem 277:43623-43630

35. Piiper A, Lutz MP, Cramer H, Elez R, Kronenberger B, Dikic I, Muller-Esterl W, Zeuzem S (2003) Protein kinase A mediates cAMP-induced tyrosine phosphorylation of the epidermal growth factor receptor. Biochem Biophys Res Commun 301:848-854
36. Poppleton H, Sun H, Fulgham D, Bertics P, Patel TB (1996) Activation of Gsalpha by the epidermal growth factor receptor involves phosphorylation. J Biol Chem 271:6947-6951

37. Edin ML, Juliano RL (2005) Raf-1 serine 338 phosphorylation plays a key role in adhesion-dependent activation of extracellular signal-regulated kinase by epidermal growth factor. Mol Cell Biol 25:4466-4475

38. Majidi M, Al-Wadei HA, Takahashi T, Schuller HM (2007) Nongenomic beta estrogen receptors enhance betal adrenergic signaling induced by the nicotine-derived carcinogen 4-(methylnitrosamino)-1-(3-pyridyl)-1-butanone in human small airway epithelial cells. Cancer Res 67:6863-6871

39. Laag E, Majidi M, Cekanova M, Masi T, Takahashi T, Schuller HM (2006) NNK activates ERK1/2 and CREB/ATF-1 via beta-1$\mathrm{AR}$ and EGFR signaling in human lung adenocarcinoma and small airway epithelial cells. Int J Cancer 119:1547-1552 